\title{
Effects of Wood Ash and Waste Glass Powder on Properties of Concrete in Terms of Workability and Compressive Strength in Jaresh City
}

\author{
Yasser I. O. Yahia, Hesham Alsharie, Manal O. Suliman, Talal Masoud \\ Department of Civil Engineering, Jaresh University, Jaresh, Jordan \\ Email: yasseribrahim646@gmail.com
}

How to cite this paper: Yahia, Y.I.O., Alsharie, H., Suliman, M.O. and Masoud, T. (2017) Effects of Wood Ash and Waste Glass Powder on Properties of Concrete in Terms of Workability and Compressive Strength in Jaresh City. Open Journal of Civil Engineering, 7, 423-431.

https://doi.org/10.4236/ojce.2017.73029

Received: July 27, 2017

Accepted: August 21, 2017

Published: August 24, 2017

Copyright $\odot 2017$ by authors and Scientific Research Publishing Inc. This work is licensed under the Creative Commons Attribution International License (CC BY 4.0).

http://creativecommons.org/licenses/by/4.0/

(c) (i) Open Access

\begin{abstract}
The potential for using fly ash as a supplementary cementing material in concrete has been known almost since the beginning of the previous century. Fly ash was used as a supplementary cementing material (SCM) in the production of Portland cement concrete. A supplementary cementing material, when used in conjunction with Portland cement, contributes to the properties of the hardened concrete through hydraulic or pozzolanic activity, or both. In this study, the fly ash and waste glass powder were used in concrete blocks to study the improvement of concrete in terms of workability and strength. Therefore, an experimental study will be conducted to measure the engineering properties of cured concrete. In this research, local raw material from Jaresh area was used.
\end{abstract}

\section{Keywords}

Fly Ash, Waste Glass Powder, Supplementary Cementing Material, Compressive Strength, Workability

\section{Introduction}

In recent decades, research has demonstrated that high dosage levels of fly ash ( $40 \%$ to $60 \%$ ) can be used in structural application producing concrete with good mechanical properties and durability (Marceau 2002) [1]. The use of good quality fly ash with a high fineness and low carbon content reduces the water demand of concrete and, consequently, the use of fly ash should permit the concrete to be produced at lower water content when compared to a Portland cement concrete of the same workability. Although the exact amount of water reduction varies widely with the nature of the fly ash and other parameters of the 
mix. A well-proportioned fly ash concrete mixture will have improved workability when compared with a Portland cement concrete of the same slump. This means that, at a given slump, fly ash concrete flows and consolidates better than a conventional Portland cement concrete when vibrated. The use of fly ash also improves the cohesiveness and reduces segregation of concrete. The spherical particle shape lubricates the mix rendering it easier to pump and reducing wear on equipment. The main objective of this paper was to develop a mixture design of concrete with fly ash and waste glass powder to produce concrete with high compressive strength comparing to normal concrete samples. Another objective was to reduce some industrial waste material on the environment such as fly ash and waste glass, which causes environment pollution.

\section{Literature Review}

Baboo Rai et al. (2011) [2] used marble powder and its granules as partial replacement for the fine aggregate. Using these materials, cement mortar and concrete were prepared. Afterwards, the relative workability test, compressive strength test and flexural strength test were conducted. Based on the test results, they concluded that when the percentage of marble powder added in concrete increases, the compressive strength and flexural strength of concrete also increase.

Akshay C. Sankh et al. (2009) [3] stated that there is a need to find the new alternative material to replace the river sand, such that excess river erosion and harm to environment is prevented. Many researchers are finding different materials to replace sand and one of the major materials is quarry stone dust. Using different proportion of these quarry dust along with sand, the required concrete mix can be obtained. This paper presents a review of the different alternatives to natural sand in preparation of mortar and concrete. The paper emphasizes on the physical and mechanical properties and strength aspect on mortar and concrete.

Belachia M. et al. (2011) [4] used the recycled aggregates in the making of hydraulic concrete. Properties like density, workability, compressive strength and flexural strength of the hydraulic concrete were found and compared with the properties of conventional concrete. The optimum percentage of recycled aggregate found from the comparative study was $25 \%$ for the ultimate strength and $50 \%$ for the ultimate density.

Goliya, H.S. et al. (2008) and ACI Committee 232 [5] [6] conducted a research with the aim of identifying a suitable alternative for concrete ingredients. Cement is replaced by fly ash, stone dust, ground granulated blast-furnace slag etc. and sand is replaced by stone dust, fly ash etc., Ravina, D. and Mehta, P. K. [7] [8]. to find out the strength properties, such as the compressive strength and flexural strength of concrete, and this through a partial replacement of both cement and sand by glass powder as a pozzolana and by pond ash in concrete respectively. 
Leema Rose. A et al. (2011) [9] showed that glass powder is obtained as a waste material after the extraction and processing of glass to form fine particles less than $4.75 \mathrm{~mm}$. Glass powder has been used in large scale in highways as a surface finishing material and also used in the manufacture of hollow blocks and light weight concrete prefabricated elements.

Monica et al. (2013) and ACAA, 2005 Coal Combustion Product [10] [11] used various alternate materials like marble powder, quarry dust, wood ash and paper pulp in concrete as a replacement of cement in making concrete. In this paper, they concluded that, by using these materials in concrete, nearly $14 \%$ to $20 \%$ of cement was saved. Chemical properties of concrete like sulfate attack resistance and alkali aggregate resistance were increased while using these materials. By using these waste materials in concrete, the problems in disposal of these materials on lands get reduced and the environmental pollution is prevented.

\section{Research Approach}

To achieve these goals, experimental laboratory tests of concrete block samples were conducted to achieve a compressive strength of $25 \mathrm{MPa}$ According: ASTM (211.1-81). The methodology of this research was divided in two main categories with the following fly ash and waste glass powder ratio:

1) Cube concrete specimen (three samples):

- Null (fly ash/waste glass powder)

- $10 \%$ of cement ratio of (fly ash/waste glass powder)

- $20 \%$ of cement ratio of (fly ash/waste glass powder)

2) Cylinder concrete specimen three samples):

- Null (fly ash/waste glass powder)

- $10 \%$ of cement ratio of (fly ash/waste glass powder)

- $20 \%$ of cement ratio of (fly ash/waste glass powder)

\section{Work Plan and Experimental Matrix}

\section{Concrete Mix Design}

According to ASTM (211.1-81) and NEVILL, we chose specific compressive strength $25 \mathrm{MPA}$ with a slump $50 \mathrm{~mm}$ and weight coarse aggregate $1600 \mathrm{~kg} / \mathrm{m}^{3}$, with maximum w/c ratio 0.5 and water content $180 \mathrm{~kg} / \mathrm{m}^{3}$ and approximate entrapped air content per cent $1.5 \%$.

\section{- Specimen Preparation}

In this research, a mix design of concrete with powder of fly ash and waste glass were used to measure and evaluate the compressive strength of concrete. The following ratio of additive powder (fly ash and waste glass) was used according to the ratio of cement:

- Null (no additive), three samples.

- A cement ratio of 10\% (fly ash and waste glass powder), at age 7 days and 28 days, three samples each for cube blocks, and two samples each for cylindri- 
cal samples.

- A cement ratio of $20 \%$ (fly ash and waste glass powder), at age 7 days and 28 days, three samples each for cube blocks, and two samples each for cylindrical samples.

- Table 1 illustrates the ratio of raw material used in concrete mix design to obtain a target compressive strength of $25 \mathrm{MPa}$.

- Sample Preparation and Notation

In this research, the samples are classified as follow:

- Pure Concrete Cube Sample (0\%, No additive material): PCCS

- Glass Concrete Cube Sample (with a ratio of $10 \%$ and 20\%): GCCS

- Fly Ash Concrete Cube Sample (with a ratio of 10\% and 20\%): FACCS

- Pure Concrete Cylindrical Sample (0\%, No additive material): PCYS

- Glass Concrete Cylindrical Sample (with a ratio of 10\% and 20\%): GCYS

- Fly Ash Concrete Cylindrical Sample (with a ratio of 10\% and 20\%): FACCYS

\section{Results Analysis and Discussion}

In this study, a concrete specimen compression test was carried out for two types of cube concrete block samples $(150 \times 150 \times 150 \mathrm{~mm})$ and cylindrical concrete samples (with a diameter of $150 \mathrm{~mm}$ and a length of $300 \mathrm{~mm}$ ).

Compression Test of Cube/Cylindrical Specimen at Age 7 Days (0\% $10 \%)$

The results of the compression test of cube samples with no additive materials at age 7 days show that the average compressive strength is $20.66 \mathrm{MPa}$ and the specific compressive strength is $9.4 \mathrm{MPa}$. On the other hand, by adding $10 \%$ of waste glass powder, the average compressive strength is $21.3 \mathrm{MPa}$ and the specific compressive strength $9.7 \mathrm{MPa}$. The average compressive strength of $10 \%$ fly ash is $31.7 \mathrm{MPa}$, and the specific compressive strength is $14.4 \mathrm{MPa}$.

The results of the compression test of cylindrical samples with no additive materials at age 7 days show that the average compressive strength is $18.7 \mathrm{MPa}$ and the specific compressive strength is $8.5 \mathrm{MPa}$. On the other hand, by adding $10 \%$ of waste glass powder, the average compressive strength is $19.4 \mathrm{MPa}$ and the Specific compressive strength is $8.8 \mathrm{MPa}$. The average compressive strength of $10 \%$ fly ash is $23.9 \mathrm{MPa}$, and the specific compressive strength is $10.7 \mathrm{MPa}$. Table 2 shows the result values.

Compression Test of Cube/Cylindrical Specimen at Age 7 Days (20\%)

Table 1. Illustrates the ratio of raw material used in concrete mix design.

\begin{tabular}{ccc}
\hline Materials & $\mathrm{Wt} / \mathrm{m}^{3}$ & Ratio (\%) \\
Water & 180 & 7.64 \\
Cement & 360 & 15.28 \\
Fine Aggregate (Sand) & 791 & 33.6 \\
Course Aggregate & 1024 & 43.48 \\
\hline
\end{tabular}


Table 2. Illustrates test results for all samples.

\begin{tabular}{|c|c|c|c|c|c|}
\hline $\begin{array}{l}\text { Sample } \\
\text { type }\end{array}$ & $\begin{array}{c}\text { Sample } \\
\text { composition }\end{array}$ & $\begin{array}{l}\text { Sample } \\
\text { Age }\end{array}$ & $\begin{array}{c}\text { Average } \\
\text { compressive } \\
\text { strength }(\mathrm{MPa})\end{array}$ & $\begin{array}{c}\text { Standard } \\
\text { Error }\end{array}$ & $\begin{array}{c}\text { Specific } \\
\text { compressive } \\
\text { strength } \\
\left(\mathrm{MPa} / \mathrm{Kg} / \mathrm{m}^{3}\right)\end{array}$ \\
\hline & Glass Powder\% & & & & \\
\hline cube & 0 & 7 & 20.66 & 0.063 & 9.4 \\
\hline- & 10 & 7 & 21.3 & 0.033 & 9.7 \\
\hline- & 20 & 7 & 14.3 & 0.088 & 6.5 \\
\hline Cylindrical & 0 & 7 & 18.7 & 0.061 & 8.5 \\
\hline- & 10 & 7 & 19.4 & 0.033 & 8.8 \\
\hline \multirow[t]{2}{*}{-} & 20 & 7 & 8.6 & 0.02 & 3.9 \\
\hline & Fly Ash\% & & & & \\
\hline cube & 10 & 7 & 31.7 & 0.052 & 14.4 \\
\hline- & 20 & 7 & 6.5 & 0.057 & 2.9 \\
\hline Cylindrical & 10 & 7 & 23.9 & 0.088 & 10.7 \\
\hline \multirow[t]{2}{*}{-} & 20 & 7 & 6.3 & 0.03 & 2.9 \\
\hline & Glass Powder\% & & & & \\
\hline cube & 0 & 28 & 24.8 & 0.031 & 11.3 \\
\hline - & 10 & 28 & 24.6 & 0.020 & 11.2 \\
\hline - & 20 & 28 & 16.4 & 0.012 & 7.5 \\
\hline Cylindrical & 0 & 28 & 21.7 & 0.031 & 9.9 \\
\hline- & 10 & 28 & 19.95 & 0.038 & 9.1 \\
\hline \multirow[t]{2}{*}{-} & 20 & 28 & 9.12 & 0.010 & 4.1 \\
\hline & Fly Ash\% & & & & \\
\hline cube & 10 & 28 & 32.5 & 0.033 & 14.8 \\
\hline - & 20 & 28 & 12.6 & 0.029 & 5.7 \\
\hline Cylindrical & 10 & 28 & 29.6 & 0.033 & 13.5 \\
\hline- & 20 & 28 & 7.41 & 0.017 & 3.4 \\
\hline
\end{tabular}

By adding $20 \%$ of waste glass powder, the results of the compression test of cube samples at age 7 days show that the average compressive strength is 14.3 $\mathrm{MPa}$ and the Specific compressive strength is 6.5. The average compressive strength of $20 \%$ fly ash is $6.5 \mathrm{MPa}$, and the specific compressive strength is 2.98 MPa.

The results of the compression test of cylindrical samples at age 7 days with adding $20 \%$ of waste glass powder, the average compressive strength is $8.6 \mathrm{MPa}$ and the specific compressive strength is $3.9 \mathrm{MPa}$. The average compressive strength of $20 \%$ fly ash is $6.3 \mathrm{MPa}$, and the specific compressive strength is 2.9 MPa. Table 2 shows the result values, and Figure 1 shows average compressive 




Figure 1. Shows the compressive strength at age 7 days for (Null, 10\%, 20\%) additive materials.

strength for cube/cylindrical sample at age 7 days.

Compression Test of Cube /Cylindrical Specimen at Age 28 Days (0\% $10 \%)$

The results of the compression test of cube samples with no additive material at age 28 days show that the average compressive strength is $24.8 \mathrm{MPa}$ and the specific compressive strength is $11.3 \mathrm{MPa}$. On the other hand, by adding $10 \%$ of waste glass powder, the average compressive strength is $24.6 \mathrm{MPa}$ and the Specific compressive strength is $11.2 \mathrm{MPa}$. The average compressive strength of $10 \%$ fly ash is $32.5 \mathrm{MPa}$, and the specific compressive strength is $14.8 \mathrm{MPa}$.

The results of the compression test of cylindrical samples with no additive material at age 28 days show that the average compressive strength s $21.7 \mathrm{MPa}$ and the specific compressive strength is $9.9 \mathrm{MPa}$. On the other hand, by adding $10 \%$ of waste glass powder the average compressive strength is $19.95 \mathrm{MPa}$ and the Specific compressive strength is 9.1. The average compressive strength of $10 \%$ fly ash is $29.6 \mathrm{MPa}$, and the specific compressive strength is $13.5 \mathrm{MPa}$. Table 2 shows the result values.

\section{Compression Test of Cube/Cylindrical Specimen at Age 28 Days (20\%)}

By adding $20 \%$ of waste glass powder, the average compressive strength of cube sample is $16.4 \mathrm{MPa}$ and the Specific compressive strength is $7.5 \mathrm{MPa}$. The average compressive strength of $20 \%$ fly ash is $12.6 \mathrm{MPa}$, and the specific compressive strength is $5.7 \mathrm{MPa}$.

The results of compression test of cylindrical samples at age 28 days with $20 \%$ waste glass powder show that the average compressive strength is $9.12 \mathrm{MPa}$ and the Specific compressive strength is $4.1 \mathrm{MPa}$. The average compressive strength of $20 \%$ fly ash is $7.41 \mathrm{MPa}$, and the specific compressive strength is $3.4 \mathrm{MPa}$. Table 2 shows the result values, and Figure 2 shows average compressive strength for cube/cylindrical sample at age 28 days.

According to the results analysis the following results discussion were drown: 




Figure 2. Shows the compressive strength at age 28 days for (Null, 10\%, 20\%) additive materials.

- Adding $10 \%$ of fly ash to concrete mixure has a significant effect to improve the compressive strength of concrete cube specimens at age 7 days, it can be reached 53\%. This is can also be linked to the work of Goliya. H. S et al. (2008) [5] who suggested that the fly ash can be used in concrete as a replacement of cement in making concrete. On the other had, the compressive strength were increased by $3 \%$ by adding $10 \%$ of waste glass.

- Adding $20 \%$ of fly ash of concrete cube result in reduction of compressive strength at age 7 days by $69 \%$, so that it can be ststed that adding $20 \%$ of fly ash gave a remarkable decrease of compressive stregnth of concrete.whereas adding $20 \%$ of waste glass to the concrete mixure resluted in decreasing of compresssive strength by $33 \%$. The standard error for all samples at age 7 days range between $0.02-0.088$, which indicated of the accurancy of the average value of compressive strength.

- At age 28 days the average compressive strength of concrete cube specimen were increased $31 \%$ by adding $10 \%$ of fly ash, so that this ratio of additive material is preferable to increase concrete strength. However, no remarkable increase of compressive strength by adding $10 \%$ of waste glass.

- Adding $20 \%$ of fly ash result in decreasing of compressive strength of concrete cube at age 28 days by $49 \%$, so that this ratio of additive material is not preferable and gave significant reduction of compressive stregnth of concrete. Whereas $20 \%$ of waste glass resulted in decrease of compressive stregnth by $33 \%$.

- For cylinderical concrete samples, the average compressive strength at age 7 days was increased by $27 \%$ by adding $10 \%$ of fly ash, so that $10 \%$ of fly ash was preferable ratio to achive a desire compressive strength. On the other hand, slight increase of compressive strength was observed when $10 \%$ of waste glass was added.

- Adding $20 \%$ of fly ash resulted in significant decrease of compressive strength $67 \%$, so that this ratio of additive materail was not preferable.on the other hand, the average compressive strength was decrease by $54 \%$ by adding $20 \%$ 
of waste glass.

- The average compressive strength for cylinderical specimen at age 28 days was increased by $36 \%$ when $10 \%$ of flyash was added, whereas an $8 \%$ decrease in compressive strength is measured, when $10 \%$ of waste glass was added. So that $10 \%$ of fly ash gave high increased of compressive strength of concrete. However, $66 \%$ decreased of compressive strength was measured by adding $20 \%$ of fly ashve. So that $20 \%$ of fly ash or more gave significant decreased of compressive strength of concrete, whereas the average compressive strength decreased by $58 \%$ by adding $20 \%$ of waste glass. The standard error for all samples at age 7 days range between $0.01-0.038$, which indicated of the accurancy of the average value of compressive strength.

\section{Conclusions and Recommendations}

The following conclusions are drawn based on the laboratory test results used in this study:

- It has been observed that adding $10 \%$ of fly ash or waste glass on concrete has a significant effect on increasing the compressive strength of concrete cube samples at age 7 days, with a range between $53 \%$ and $3 \%$.

- The measurements show that the compressive strength of concrete is increased by $31 \%$, when $10 \%$ of fly ash is added and a $1 \%$ reduction of compressive strength is achieved, by adding $10 \%$ of waste glass on concrete at age 28 days.

- The measurements show that the reduction of compressive strength of concrete at age 7 days varies between $69 \%$ and $30 \%$, when $20 \%$ of waste glass and fly ash is added to concrete.

- It has been observed that adding $10 \%$ of fly ash or waste glass to concrete resulted in an increase in the compressive strength of concrete cube samples at age 28 days, ranging between $31 \%$ and $1 \%$ respectively. It is also observed that there was a significant reduction of compressive strength at age 28 days, ranging between $33 \%$ and $49 \%$, when adding $20 \%$ of waste glass and fly ash respectively.

- In conclusion, adding $20 \%$ of waste glass or fly ash is not recommended, since it leads to a significant decrease in the compressive strength of concrete.

- Adding $10 \%$ of fly ash results in a significant increase in the compressive strength of concrete.

- The small value of standard error for all samples indicated that how the average compressive strength was accurate.

- Further experimental studies are needed to understand the behaviour of Jersh row material of concrete such as coarse aggregate and fine aggregate.

\section{References}

[1] Marceau, M.L., Gajda, J. and VanGeem, M.G. (2002) Use of Fly Ash in Concrete: Normal and High Volume Ranges. PCA R\&D Serial No. 2604, Portland Cement 
Association, Skokie.

[2] Rai, B. and Naushad, K. (2011) Marble Powder Concrete. International Journal of Engineering Sciences Research-IJESR, 3, 68.

[3] Akshay, S.C. and Naghathan, S.J. (2009) Experimental Investigation of Waste Quarry Stone Dust as the Partial Replacement of Sand in Concrete Production. International Journal of Advanced Technology in Civil Engineering, 3, 45-53.

[4] Belachia, M. and Hebhoub, H. (2011) Effects of Recycled Aggregates on Fresh Concrete. Indian Journal of Science and Technology, 3, 11-19.

[5] Goliya, H.S. and Mahajan, M. (2008) Effects of Glass Powder and Pond Ash on Concrete Strength. International Journal on Design and Manufacturing Technologies, 3, No.3.

[6] ACI Committee 232 (1996) Use of Fly Ash in Concrete. American Concrete Institute, Farmington Hills, 41.

[7] Ravina, D. and Mehta, P.K. (1986) Properties of Fresh Concrete Containing Large Amounts of Fly Ash. Cement and Concrete Research, 16, 227-238. https://doi.org/10.1016/0008-8846(86)90139-0

[8] Ravina, D. and Mehta, P.K. (1988) Compressive Strength of Low Cement/High Fly Ash Concrete. Cement and Concrete Research, 18, 571-593.

https://doi.org/10.1016/0008-8846(88)90050-6

[9] Leema Rose, A. and Saji, M.S. (2011) Usage of Glass Powder in Manufacturing of Concrete. Indian Journal of Science and Technology, 2, 11-16.

[10] Monica and Dhoka, C. (2013) Effects of Various Waste Materials on Compressive Strength of Concrete. Indian Journal of Science and Technology, 5, 17-22.

[11] ACAA (2006) 2005 Coal Combustion Product (CCP) Production and Use Survey. American Coal Ash Association. www.acaa-usa.org

\section{Submit or recommend next manuscript to SCIRP and we will provide best} service for you:

Accepting pre-submission inquiries through Email, Facebook, LinkedIn, Twitter, etc.

A wide selection of journals (inclusive of 9 subjects, more than 200 journals)

Providing 24-hour high-quality service

User-friendly online submission system

Fair and swift peer-review system

Efficient typesetting and proofreading procedure

Display of the result of downloads and visits, as well as the number of cited articles

Maximum dissemination of your research work

Submit your manuscript at: http://papersubmission.scirp.org/

Or contact ojce@scirp.org 